\title{
SOME CONIFERS FROM THE EARLY CRETACEOUS (LATE APTIAN - EARLY ALBIAN) OF CATEFICA, LUSITANIAN BASIN, WESTERN PORTUGAL
}

\author{
MÁRIO MIGUEL MENDES ${ }^{1, *}$, PEDRO DINIS², JIŘÍ KVAČEK ${ }^{3}$ \\ ${ }^{1}$ CIMA - Centre for Marine and Environmental Research, Universidade do Algarve, Campus Universitário de Gambelas, 8005-139 Faro, \\ Portugal; e-mail:mmmendes@mail.telepac.pt \\ ${ }^{2}$ MARE - Marine and Environmental Sciences Centre, Departamento de Ciências da Terra da Universidade de Coimbra, Largo Marquês de \\ Pombal, 3000-272 Coimbra, Portugal; e-mail: pdinis@dct.uc.pt. \\ 3 Department of Palaeontology, National Museum, Václavské nám. 68, 11000 Praha 1, the Czech Republic; e-mail: jiri_kvacek@nm.cz. \\ * corresponding author
}

Mendes, M. M., Dinis, P., Kvaček, J. (2018): Some conifers from the Early Cretaceous (late Aptian - early Albian) of Catefica, Lusitanian Basin, western Portugal. - Fossil Imprint, 74(3-4): 317-326, Praha. ISSN 2533-4050 (print), ISSN $2533-4069$ (on-line).

\begin{abstract}
Several mesofossil floras discovered in the Early Cretaceous rocks from the Lusitanian Basin of western Portugal comprise numerous well-preserved conifer remains. Here we report the occurrence of four conifer types in the mesofossil flora from the Catefica locality, about $4 \mathrm{~km}$ south of Torres Vedras in the Estremadura region on the western Portuguese Basin. The specimens were recovered from rocks belonging to the Almargem Formation, interpreted to be of late Aptian - early Albian age. It includes three Cheirolepidiaceae genera Frenelopsis SCHENK, Pseudofrenelopsis NATH. and Watsoniocladus V.SRINIV., and one conifer twig of Pagiophyllum-type. These conifers, which co-occurred in the same depositional bed with a well-diversified early angiosperm assemblage including flowers, seeds, fruits and dispersed stamens with pollen in situ, provide new insights into Early Cretaceous palaeoecology.
\end{abstract}

Key words: conifers, mesofossil floras, Early Cretaceous, Almargem Formation, Catefica, Portugal

Received: October 24, 2018 | Accepted: November 28, 2018 | Issued: December 28, 2018

\section{Introduction}

Conifers are the most successful and widespread group of extant gymnosperms (Farjon 2010, Farjon and Filer 2013). They evolved from the late Carboniferous onward and attained their greatest abundance and diversity during the Mesozoic (Hernandez-Castillo et al. 2001, Plotnick et al. 2009). In the Mesozoic, particularly during the Jurassic and Cretaceous, conifers were an important component of plant communities and played an important role in terrestrial ecosystems.

Conifer remains are very common in the mesofossil floras from the Lower Cretaceous strata of the Lusitanian Basin in western Portugal, and these studies have yielded new and important information about plant composition and evolution through the Cretaceous (e.g. Friis et al. 1994, 1999, 2010, Mendes et al. 2011, 2014).

The Catefica locality is a road cut between the villages of Catefica and Mugideira about $4 \mathrm{~km} \mathrm{SSE}$ of Torres Vedras on the western Portuguese Basin. The mesofossil flora from Catefica was first documented by Friis et al. (1994) from light cross-bedded sands with some darker clay beds rich in plant fragments, and is mostly known for its diversity of angiosperm remains, but also contains an astonishing variety of gymnosperms, mainly conifers (e.g. Friis et al. 1994, 1999, 2009, 2010, 2011, 2013, 2014, 2015a, b, 2018, Mendes et al. 2017).

In this paper we describe the occurrence of four conifer types, which co-occurred with a number of angiosperm mesofossils, forming a unique association in the Catefica flora.

\section{Material and methods}

The fossil specimens documented herein were extracted from six rock samples $(310,311,315,316,317$ and 318) collected in 2016 by two of us (M. M. Mendes and P. Dinis) from the same plant-bearing horizon in the Catefica exposure ( $\left.39^{\circ} 3^{\prime} 14.4^{\prime \prime} \mathrm{N} ; 9^{\circ} 14^{\prime} 24.1^{\prime \prime} \mathrm{W}\right)$, in the Estremadura region, Lusitanian Basin, western Portugal (Text-fig. 1). Samples were collected from a dark clay bed belonging to the Almargem Formation and assigned to the "Grés de Torres Vedras" unit (Carta Geológica de Portugal, Folha 30-D 
Alenquer; Zbyszewski and Assunção 1965), probably of late Aptian to early Albian in age (Mendes et al. 2017). In the laboratory, the rock samples were disaggregated in water, and washed using a shower through a $125-\mu \mathrm{m}$-mesh sieve. The bulk organic matter was cleaned first in $40 \%$ hydrofluoric acid (HF), and second in $10 \%$ hydrochloric $(\mathrm{HCl})$ acid to remove adhering minerals. They were then thoroughly rinsed in water and dried in air, following standard methods previously described by Friis et al. (1988). Plant fossils were initially investigated under a stereomicroscope. The conifer specimens are both flattened (Frenelopsis SCHENK and Pseudofrenelopsis NAтH.) and only slightly compressed and in three-dimensional shape (Watsoniocladus V.SRINIV. and Pagiophyllum-type conifer).

The specimens selected for more detailed study were mounted on polished aluminium stubs, sputter coated with gold for 60 seconds and examined using a Hitachi Field $\mathrm{S}-4300$ scanning electron microscope (FE-SEM) at $2 \mathrm{kV}$ at the Swedish Museum of Natural History, Stockholm.

All photographs were improved for both brightness and contrast, and to remove background irregularities using Adobe Photoshop CS6 software.

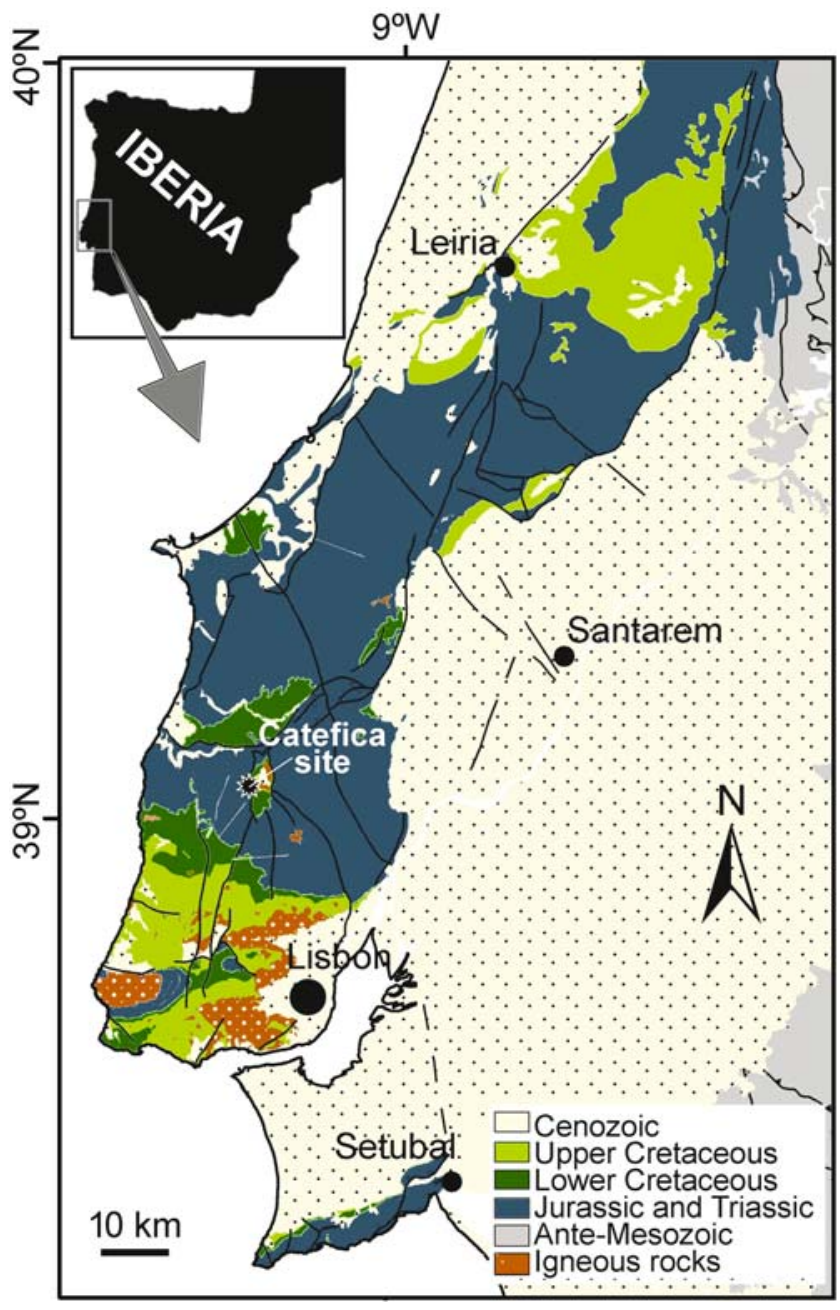

Text-fig. 1. Geographical position of the Lusitanian Basin in the western part of the Iberian Peninsula, and detailed map showing the approximate location of the Catefica site where the specimens were collected, indicated by an asterisk.
The fossil specimens are housed in the palaeobotanical collections of the Geological Museum of Lisbon, Portugal (P numbers).

\section{Geological setting}

The Catefica outcrop exposure is approximately $4.50 \mathrm{~m}$ high, and shows three lithological units (Text-fig. 2):

(a) The lower unit mainly consists of white to light grey trough cross-bedded pebbly sandstones. Decimetre-thick mudstone lenses are occasionally interbedded. The contact with the middle unit is occasionally highlighted by a cmthick iron crust.

(b) The middle unit consists of structureless or crossbedded, fine to medium-grained sandstones interbedded with organic-rich horizontal laminated, silt-dominated mudstones and very fine-grained sandstones. These beds are lens-shaped, decimetre- to metre-thick, and can be traced laterally for several metres, being organised in an inclined heterolithic depositional unit. The fine to medium-grained sandstones are usually white or light grey, and show a concave lower surface and plane upper surface, although a plane lower surface and convex upper surface also occur. This unit also shows load casts in its lower portion and pedogenetic tubular mottles near the top. The rock samples containing the conifer fossils studied herein were collected from the organic-rich fine-grained beds.

(c) The upper unit consists of yellowish-brown or grey trough cross-bedded pebbly sandstones, and is characterised by amalgamated metre-thick concave-up beds. Its lower boundary is a sharp erosive surface that can be associated with over-sized mudclasts, up to $10-20 \mathrm{~cm}$ in diameter.

Rey (1993) interpreted this succession as related to a system of relatively large braided rivers. The lithology and geometry of the middle unit suggest that it is probably related to a lateral accretion architectural element generated by sinuous channels within this river system. Similar environments were described elsewhere (e.g. Makaske and Nap 1995, Miall 1996). The fine-grained beds containing the plant mesofossils were probably deposited during periods of low discharge into the site. The presence of load casts indicates that renewed discharge responsible for sand deposition occurred when the fine-grained beds were still wet. High sedimentation rates account for the low oxidation and bioturbation, which are common only near the top of this middle unit. The amalgamated coarse-grained beds of the upper unit are attributed to a higher energy episode. Steeper relief and the presence of highly mobile channels explain the absence of fine-grained beds within this upper unit.

On the basis of the sharp unconformities and lithological contrast, the three units may correspond to distinct stratigraphic intervals. The lower unit was probably deposited during a sea level highstand that Rey (1993, 2006) considered as belonging to the lower member of the Almargem Formation, which is early Aptian in age (for a more detailed account of the geology see Mendes et al. 2017). The rock samples containing the studied conifer mesofossils were collected from a dark clay bed of the middle unit, probably belonging to the base of the upper member of the Almargem Formation, which is likely of late Aptian to early Albian age (Mendes et al. 2017). 

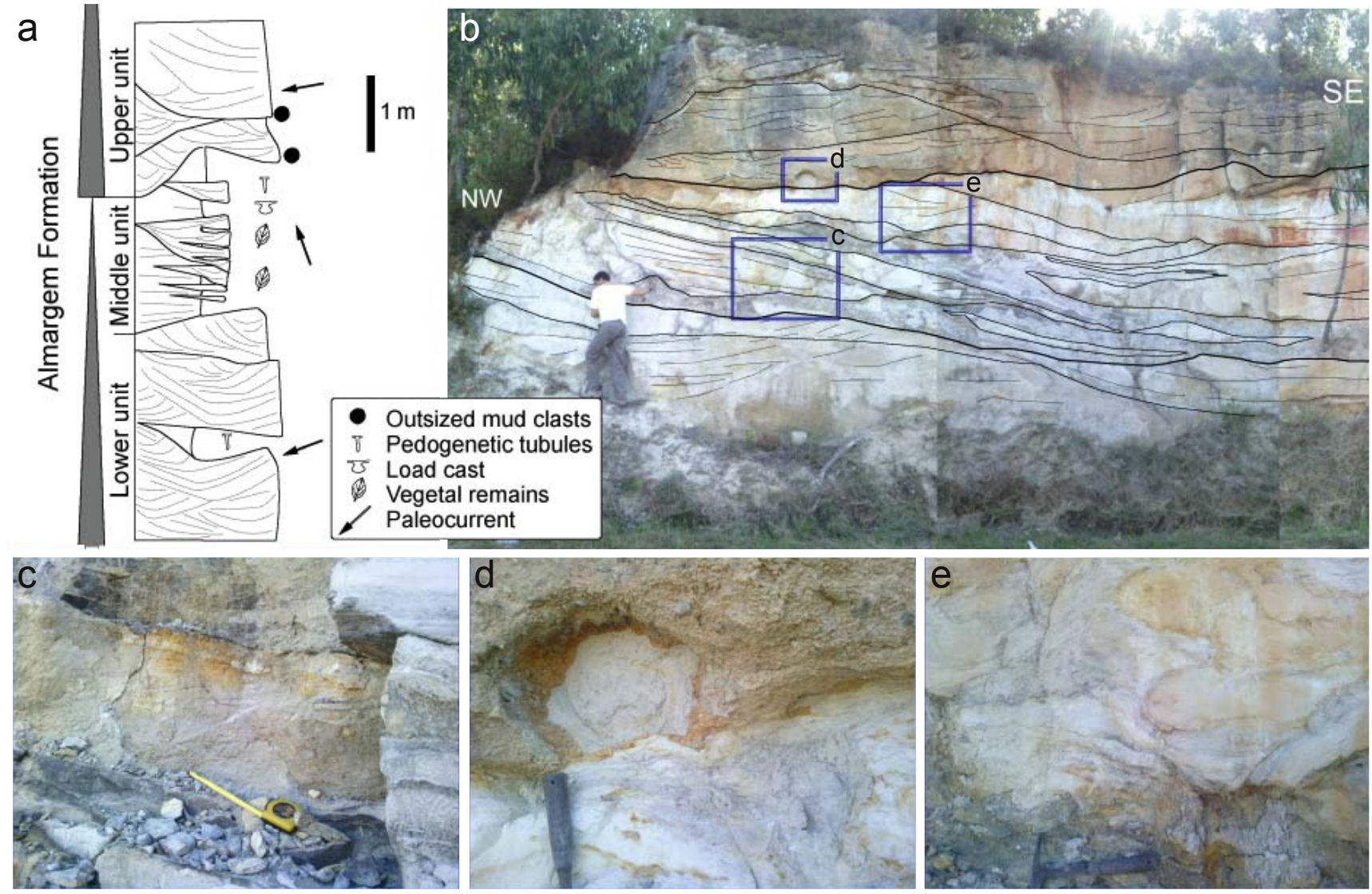

Text-fig. 2. The Catefica locality. (a) Stratigraphic log. (b) General view of the Catefica outcrop. (c) Detail of the fine-grained organic rich fossil beds between sandstones. (d) Out-sized mud clasts at the base of the upper unit. (e) Load casts in the middle unit.

\section{Systematic palaeobotany}

\section{Order Coniferales \\ Family Cheirolepidiaceae TАКнт., 1963}

\section{Genus Frenelopsis Schenk, 1869}

Ty p e. Frenelopsis hoheneggeri (EtTIngsh.) Schenk, 1869 , p. 13 , pl. 4 , figs $5-7$, pl. 5, figs $1-2$, pl. 6, figs $1-6$, pl. 7 , fig. 1 .

\section{Frenelopsis cf. turolenis B.GoMez in Gomez et al., 2002} Text-fig. $3 \mathrm{a}-\mathrm{c}$

D e s c ription. Shoot fragments from bulk macerated material consist of one or two internodes - whorls of three fused leaves each. Whorls alternate at $60^{\circ}$. Leaves are fused along almost their entire lengths, forming an internode (sheath) with no suture in between. The internodes show terminally short triangular free tips with scarious margins (Text-fig. 3a) being up to $13 \mathrm{~mm}$ long, and $4 \mathrm{~mm}$ wide (the latter corresponding to half a perimeter). The three leaf tips are usually less than $0.5 \mathrm{~mm}$, but they are $2.1 \mathrm{~mm}$ in one specimen (Text-fig. 3a). Cuticle surface is papillate to generally smooth. Stomata are arranged in parallel but rather ill-defined longitudinal rows running along to the internode axis. They have typically 4 , but sometimes 5 subsidiary cells, each bearing outer papillae (Text-fig. 3c, arrowed). The compound structure of the stomatal chamber shows inner and outer papillae (Text-fig. 3c, arrowed).
D i s c u s s i o n. Through the present, based on the study of their cuticles, up to 20 species of Frenelopsis have been described from the Valanginian - Maastrichtian of Belgium, China, the Czech Republic, France, Germany, Goban Spur, Greenland, Italy, Japan, Poland, Portugal, Spain, Sudan, Tajikistan, Ukraine and USA (e.g. Watson 1988, Kvaček 2000, Gomez et al. 2002, 2008, Mendes et al. 2010, Bartiromo et al. 2012, Batten et al. 2014, Barral et al. 2016).

The studied material most closely matches Frenelopsis turolenis from the Albian of Spain, but has some characters in common with F. ugnaensis B.Gomez from the Barremian of Spain (Gomez et al. 2002). Our material shares the characters of a small inner papillae and a cuticle that is rather papillate, but not hairy, with F. ugnaensis. Therefore, we leave it for further study to determine whether the material definitively belongs to $F$. turolensis. Both species show cuticles with stomata arranged in rows. Their stomata are surrounded by typically four subsidiary cells. Typical number of subsidiary cells is a character in which our material differs from other three-leaved Frenelopsis species with approximately smooth cuticle: F. rubiescensis BARALE from the Berriasian Barremian of Spain (Gomez et al. 2002), F. occidentalis HeER from the Early Cretaceous of Portugal and Germany (Alvin 1977), F. oligostomata Romariz from the Late Cretaceous of Portugal and Spain, F. kanevensis BARAle et Doludenko from the Albian of Ukraine (Barale and Doludenko 1985). F. ramosissima FonTAINE from Barremian - Albian of the USA (Berry 1910, Watson 1977) differs from our material in having stomata surrounded typically by five subsidiary cells and round rim of stomatal pit. 


\section{Genus Pseudofrenelopsis NaTH., 1893}

Type. Pseudofrenelopsis felixii NATH. in Felix and Nathorst 1893, p. 52, text-figs 6-9.

N ote. The genus was emended by Watson (1977) and we accept this emendation here.

\section{Pseudofrenelopsis cf. parceramosa (Fontaine) \\ J.WATSON, 1977 \\ Text-fig. $3 \mathrm{~d}-\mathrm{f}$}

Description. The studied mesofossils represent fragments of axes and single stocky leaves. The axes consist of nodes and internodes. Each leaf shows one short free tip (Textfig. $3 \mathrm{~d}$ ). The flat internodes are up to $6.9 \mathrm{~mm}$ long and $3.6 \mathrm{~mm}$ wide (the latter corresponding to half a perimeter). The distal margins of leaves bear dense, long, hairy papillae. The leaf tips are up to $0.7 \mathrm{~mm}$ long. Stomata are arranged in well-defined parallel longitudinal rows running parallel to the internode axis
(Text-fig. 3e). Stomata are circular to elliptical in outline and show a raised elliptical rim (Text-fig. 3f, arrowed). They are surrounded by about 5 papillae set on periclinal walls of the same number of subsidiary cells (Text-fig. 3f, arrowed).

Discussion. Pseudofrenelopsis includes 12 species that have been reported from the Berriasian - Albian in Brazil, the Czech Republic, China, Columbia, England, Mexico, Korea, Poland, Portugal, Spain, Sudan and USA (e.g. Nathorst 1893, Reymanówna and Watson 1976, Watson and Alvin 1976, Alvin 1977, Watson 1977, 1983, 1988, Alvin et al. 1981, Zhou 1983, Hluštík 1988, Srinivasan 1995, Saiki 1999, Deng et al. 2005, Axsmith 2006, Moreno Sánchez et al. 2007, Yang and Deng 2007, Mendes et al. 2010, Sun et al. 2011, Kim et al. 2012, Hill et al. 2012, Villanueva-Amadoz et al. 2014, Sucerquia et al. 2015, Peixoto Batista et al. 2017).

The studied material shows important diagnostic characters of $P$. parceramosa - smooth cuticle with stomata
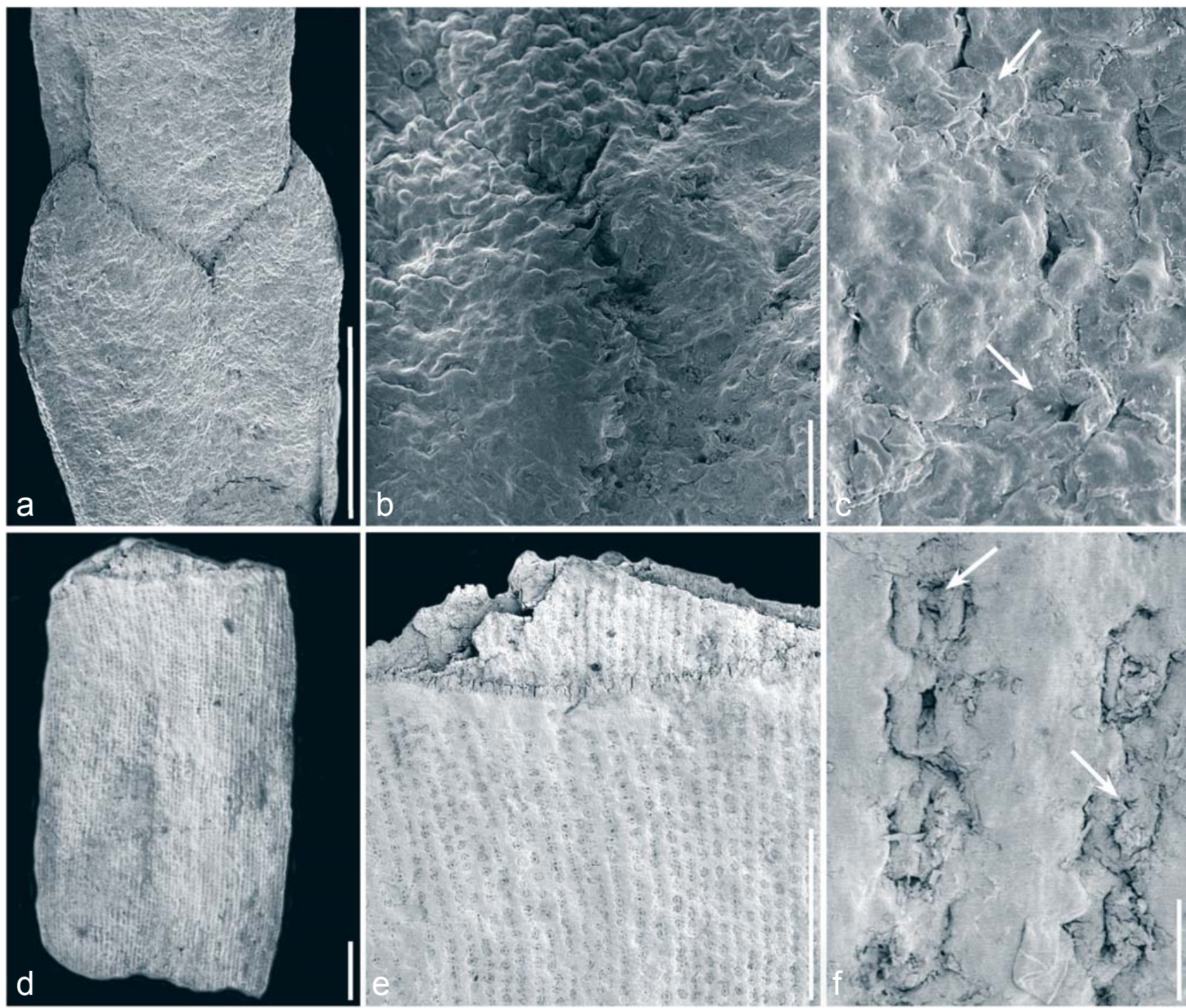

Text-fig. 3. SEM micrographs of two types of conifers from the Early Cretaceous mesofossil flora of Catefica, Portugal. (a) Shoot fragment of Frenelopsis turolensis with terminally short triangular free tips (P0357, sample Catefica 310). (b) Outer surface with papillae and stomata arranged in longitudinal rows (P0357, sample Catefica 310). (c) Stomatal chamber with outer and inner papillae (arrows) (P0357, sample Catefica 310). (d) Flat internode of Pseudofrenelopsis cf. parceramosa (P0132, sample Catefica 315). (e) Outer view of the abaxial surface showing stomatal rows (P0132, sample Catefica 315). (f) Detail of stomatal rows showing massive rings around the stomatal pits (arrows) (P0132, sample Catefica 315). Scale bars =1 mm (a, d, e); $100 \mu \mathrm{m}$ (b); $50 \mu \mathrm{m}$ (f); $5 \mu \mathrm{m}$ (c). 
arranged in well-defined rows (Alvin 1977, Watson 1977). The aperture of the stomatal pit is rounded, formed by a well-developed rim (Florin ring). However, its papillae on subsidiary cells sunken in stomatal pits are not always visible. In this preliminary study we assign it to the species P. parceramosa, which was described by Alvin (1977) from the Early Cretaceous of Portugal. This species was reported from the Late Cretaceous of USA (Fontaine 1889, Watson 1977), Portugal (Alvin 1977), Great Britain (Watson and Alvin 1976, Alvin et al. 1981, Watson 1977, 1983, 1988), Poland (Reymanówna and Watson 1976) and is generally one of the best known frenelopsids (Watson 1988).

\section{Genus Watsoniocladus V.SRINIV., 1995}

Ty p e. Watsoniocladus valdensis (SEwARD) V.SRINIV., 1995 , p. $267 \equiv$ Thuites valdensis SEWARD, 1895, p. 209, pl. 20, fig. 6 .

\section{Watsoniocladus cf. virginiensis V.SRINIV., 1995 Text-fig. 4a-g}

Description. These conifer twigs consist of unbranched stems bearing decussately or semi-decussately arranged leaves of Brachyphyllum-type. They are usually borne so tightly together along the stems that the latter are not visible (Text-fig. 4a, e). The apices are usually pointed and falcate in outline, but some specimens show the most distal leaves being rounded (Text-fig. $4 \mathrm{e}, \mathrm{f}$ ). The leaves are up to $2.5 \mathrm{~mm}$ long and $1.2 \mathrm{~mm}$ wide. The abaxial surfaces are convex and keeled, whilst the adaxial surfaces are concave and unkeeled. The leaves are amphistomatic. Ordinary cells of abaxial cuticle bear papillae, particularly in their terminal parts. The stomata are surrounded by a raised rim with finger-like outer papillae. The papillae form star-shaped stomatal apertures (Text-fig. 4d, arrowed). The stomata are arranged in ill-defined rows (Text-fig. 4c).

Discussion. Based on the opposite decussate leaf arrangement and cuticle characters, the present fossil material is ascribed to the genus Watsoniocladus. Watsoniocladus consists of at least 6 species collected from the Early Jurassic - Albian of England, France, Germany, Israel, Iran, Japan, Spain and USA (e.g. Watson and Alvin 1999, Srinivasan 1995, Néraudeau et al. 2012, Buscalioni et al. 2018). Due to presence of elongate leaves and papillae borne rather outside then inside the stomatal pits, we compare the studied material with $W$. virginensis V. SRINIV. and $W$. florinii V.SRINIV. described from the Early Cretaceous (early to middle Albian) flora of the Potomac Group in eastern North America (Srinivasan 1995). Both species have papillae and trichomes on their outer abaxial surfaces, papillate stomatal rims and stomata arranged in ill-defined stomatal rows. The present material shows separate leaves, and is therefore assigned to $W$. virginiensis rather than to $W$. florinii, in which adjacent leaves are fused (Srinivasan 1995).

\section{Family indet.}

\section{Fossil-Genus Pagiophyllum HeEr, 1881}

Ty p e. Pagiophyllum crinicum (SAPORTA) HeEr, 1881, p. 11 , pl. 10, fig. $6 \equiv$ Pachyphyllum crinicum SAPORTA, 1873, p. 37.
Note. The material described here is preliminarily assigned to the genus Pagiophyllum. It shows that genus's principal diagnostic characters: helically arranged leaves in which length exceeds their width (Harris 1969). It differs from Geinitzia EndL. and Elatides Halle in lacking any reproductive structure. From Cunninghamites C.PRESL it differs in having leaves triangular in cross-section, usually falcate and lacking the conspicuous leaf base cushion and corresponding scar (Kvaček 1999, Bosma et al. 2012).

\section{Pagiophyllum sp. \\ Text-fig. 4h, i}

Description. The fragmentary shoot specimens consist of long, slender leaves arranged helically along unbranched axes (Text-fig. 4h). The leaves are up to 3 $\mathrm{mm}$ long and $0.6 \mathrm{~mm}$ wide. Their leaf cushion is narrowly elongate. They represent a continuation of a basal part of the leaf, without any particular broadened part (Text-fig. 4h). The abaxial surfaces are convex and keeled, whilst the adaxial surfaces are concave. Leaf margins show tiny, regular teeth (Text-fig. 4i). Leaves hypostomatic, stomata lack papillae.

Discussion. This taxon shows helically arranged leaves with stomata lacking papillae. It provides completely different characteristics than the first described group of conifers belonging to the Cheirolepidiaceae. Its stomata do not show any papillae. This type of foliage with falcate, helically arranged leaves may indicate Cupressaceae s.l., but its stomata are not arranged in bands. Due to its fragmentary preservation, the material is left in open nomenclature and its systematic affinity remains questionable. Additional studies should provide more details to its more precise identification.

\section{Discussion and conclusions}

Co-occurrences of Frenelopsis plus Pseudofrenelopsis (e.g. Watson 1977, 1983, Hluštík 1988, Mendes et al. 2010, Moreno Sánchez et al. 2007), Pseudofrenelopsis and Watsoniocladus (e.g. Watson and Alvin 1996)) and Frenelopsis and Watsoniocladus (e.g. Watson and Alvin 1999, Buscalioni et al. 2018) in the same plant assemblage have been reported several times. However, all three, Frenelopsis, Pseudofrenelopsis and Watsoniocladus were previously only collected together once, from the Puddledock locality (Potomac Group, Early Cretaceous) in eastern North America (Srinivasan 1995). Remarkably, the Puddledock mesofossil flora is highly diverse, including bryophytes, lycopods, ferns, conifers, and angiosperm flowers and fruits (Friis et al. 2009 and references therein). The Catefica mesofossil flora is similar to the latter, comprising well-preserved angiosperm flowers, fruits and seed as well as dispersed stamens with pollen in situ, conifers, numerous fragments of ferns and thalloid liverworts, several selaginellaceous shoots and megaspores. Classopollis pollen grains are very abundant in the Catefica palynoflora (Mendes et al. 2017), as well as in the Potomac Group (Tanrikulu et al. 2018), suggesting a dominance of cheirolepidiaceous conifers in the warm temperate and subtropical Early Cretaceous 

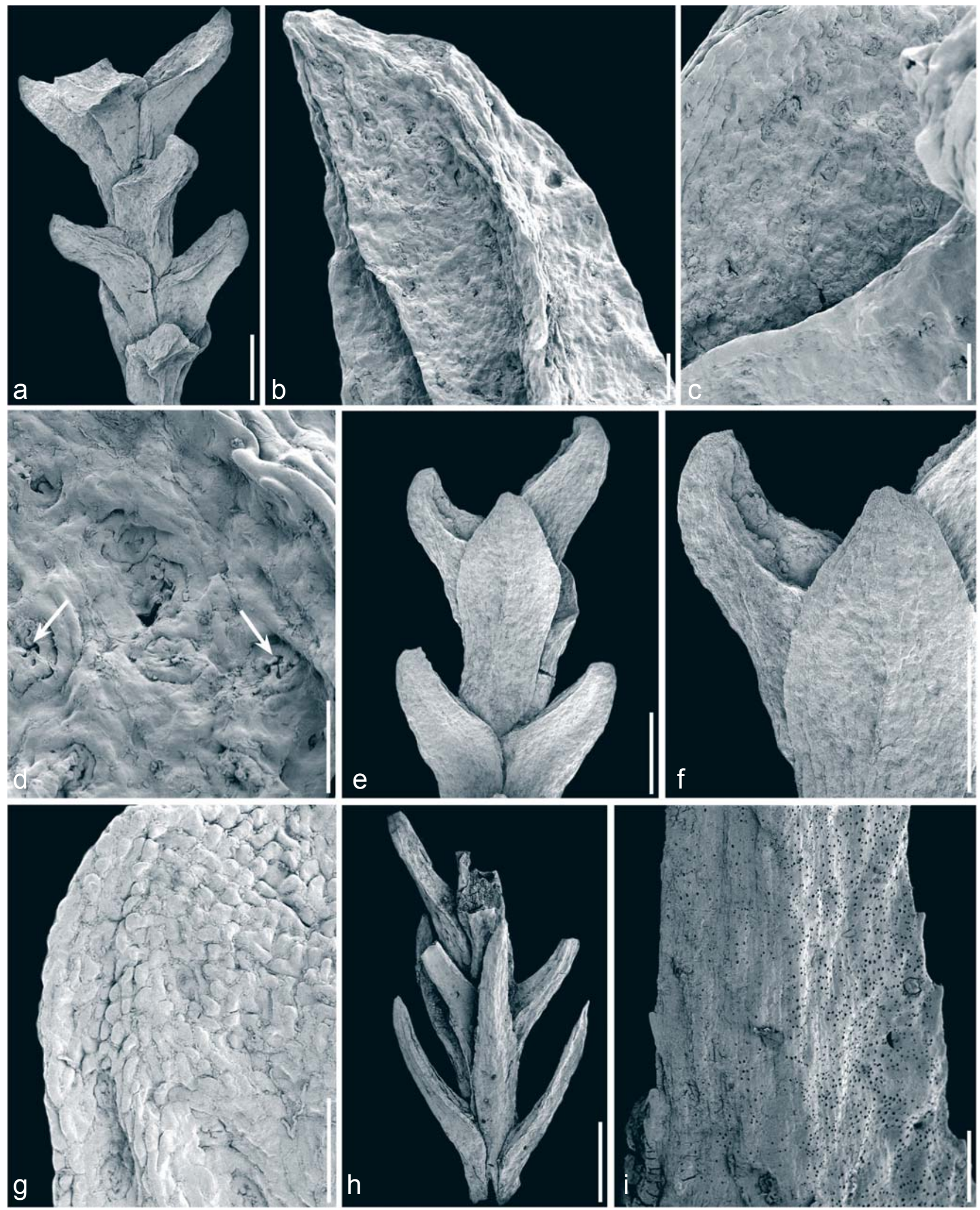

Text-fig. 4. SEM micrographs of two types of conifers from the Early Cretaceous mesofossil flora of Catefica, Portugal. (a) Leafy twig of Watsoniocladus cf. virginiensis with opposite-decussate leaves showing convex, keeled, abaxial surface and concave, unkeeled, adaxial surface (P0127, sample Catefica 316). (b), (c) Details of the leaf apex showing amphistomatic abaxial and adaxial surfaces (P0127, sample Catefica 316). (d) Detail of stomata surrounded by a raised rim with finger-like outer papillae showing star-shaped stomatal apertures (arrows) (P0127, sample Catefica 316). (e), (f) Leafy twig of Watsoniocladus cf. virginiensis showing hook-shaped leaves in outline (P0129, sample Catefica 317). (g) Detail of the abaxial surface showing stomata arranged in ill-defined rows (P0129, sample Catefica 317). (h) Leafy twig of Pagiophyllum sp. showing convex, keeled, abaxial surface and concave, unkeeled, adaxial surface (P0126, sample Catefica 318). (i) Detail of the abaxial leaf surface showing serrate margin and scattered stomata (P0126, sample Catefica 318). Scale bars $=1$ mm (a, e, f, h); $100 \mu \mathrm{m}(\mathrm{b}, \mathrm{c}, \mathrm{g}, \mathrm{i}) ; 50 \mu \mathrm{m}(\mathrm{d})$. 
palaeoenvironments. Frenelopsis and Pseudofrenelopsis are usually reconstructed as shrubs and trees (Alvin 1983, Watson 1988, Axsmith 2006, Barral et al. 2016). Such a long-lived conifer tree forest was certainly a diversified plant ecosystem. We can speculate that early angiosperms could occur in its understory. Some palaeoclimate data has indicated a global warming and increased precipitation during the late Aptian - early Albian in the Lusitanian Basin (e.g. Heimhofer et al. 2012, Bonin et al. 2016). This climate change could be one of the reasons for increased angiosperm abundance, and their eventual dominance (Coiffard et al. 2012).

\section{Acknowledgement}

This research was supported by grants from the Amadeu Dias Foundation, the Portuguese Science Foundation (FCT) grant UID/MAR/00350/2013 to CIMA of the University of Algarve. JK was financially supported by the Ministry of Culture of the Czech Republic (DKRVO 2018/05, National Museum, 00023272). We are also grateful for their comments to Johanna H. A. van Konijnenburg-van Cittert (Naturalis, Biodiversity Center, Leiden) and Alexei Herman (Geological Institute, Russian Academy of Sciences, Moscow), who reviewed the manuscript.

\section{References}

Alvin, K. L. (1977): The conifers Frenelopsis and Mani$c a$ in the Cretaceous of Portugal. - Palaeontology, 20: 387-404.

Alvin, K. L. (1983): Reconstruction of a Lower Cretaceous conifer. - Palaeontology, 86: 169-176. https://doi.org/10.1111/j.1095-8339.1983.tb00724.x

Alvin, K. L., Fraser, C. J., Spicer, R. A. (1981): Anatomy and palaeoecology of Pseudofrenelopsis and associated conifers in the English Wealden. - Palaeontology, 24: 759-778.

Axsmith, B. J. (2006): The vegetative structure of a Lower Cretaceous conifer from Arkansas: further implications for morphospecies concepts in the Cheirolepidiaceae. Cretaceous Research, 27: 309-317.

https://doi.org/10.1016/j.cretres.2005.07.001

Barale, G., Doludenko, M. (1985): Une nouvelle espèce de Cheirolepidiaceae de l'Ablien supérieur d'URSS: Frenelopsis kaneviensis nov. sp. - Comptes Rendus du 100. Congrès National des Sociétés Savantes (Montpellier 1985), 5: 99-114.

Barral, A., Gomez, B., Zorrilla, J. M., Serrano, J. M., Yans, J., Cazedebat, M., Daviero-Gomez, V., Ewin, T. A. M., Lécuyer, C. (2016): Local-scale analysis of plant community from the Early Cretaceous riparian ecosystem of Hautrage, Belgium. - Palaeogeography, Palaeoclimatology, Palaeoecology, 443: 107-122.

https://doi.org/10.1016/j.palaeo.2015.11.026

Bartiromo, A., Barale, G., Barone Lumaga, M. R., Bravi, S., Barattolo, F. (2012): An Early Cretaceous flora from Cusano Mutri, Benevento, southern Italy. - Cretaceous Research, 33: 116-134.

https://doi.org/10.1016/j.cretres.2011.09.006
Batten, D. J., Zhou, Z. Y., Li, W. B. (2014): Plant remains from Early Cretaceous deposits on the Goban Spur, Bay of Biscay, North Atlantic Ocean, and their palaeoenvironmental significance. - Palaeoword, 23: 162-186. https://doi.org/10.1016/j.palwor.2013.11.004

Berry, E. W. (1910): The epidermal characters of Frenelopsis ramossisima. - Botanical Gazette, 50: 305-309. https://doi.org/10.1086/330364

Bonin, A., Pucéat, E., Vennin, E., Mattioli, E., Aurell, M., Joachimski, M., Barbarin, N., Laffont, R. (2016): Cool episode and platform demise in the Early Aptian: New insights on the links between climate and carbonate production. - Paleoceanography, 31: 66-80. https://doi.org/10.1002/2015PA002835

Bosma, H. F., Kunzmann, L., Kvaček, J., van Konijnenburgvan Cittert, J. H. A. (2012): Revision of the genus Cunninghamites (fossil conifers), with special reference to nomenclature, taxonomy and geological age. - Review of Palaeobotany and Palynology, 182: 20-31 https://doi.org/10.1016/j.revpalbo.2012.06.004

Buscalioni, A. D., Martín-Closas, C., Delvene, G., Munt, M. C., Barral, A., Tinner-Grellet, G., Gomez, B., DavieroGomez, V., Chamero, B. (2018): Taphonomy and palaeoecology in the upper Barremian of the SW Iberian chain (Spain): A model to compare taxonomy and diversity of biotas from different coeval basins. - Palaeogeography, Palaeoclimatology, Palaeoecology, 490: 305-324. https://doi.org/10.1016/j.palaeo.2017.11.009

Coiffard, C., Gomez, B., Daviero-Gomez, V. (2012): Deciphering early angiosperm landscape ecology using a clustering method on Cretaceous plant assemblages. In: Tiefenbacher, J. (ed.), Perspectives on Nature Conservation - Patterns, Pressures and Prospects. InTech, Rijeka, pp. 33-50. https://doi.org/10.5772/32125

Deng, S., Yang, X., Lu, Y. (2005): Pseudofrenelopsis (Cheirolepidiaceae) from the Lower Cretaceous of Jiuquan, Gansu, northwester China. - Acta Palaeontologica Sinica, 44: 505-516.

Farjon, A. (2010): A handbook of the world's conifers. - Brill Academic Publishers, Leiden, 1150 pp. https://doi.org/10.1163/9789047430629

Farjon, A., Filer, D. (2013): An atlas of the world's conifers: An analysis of their distribution, biogeography, diversity and conservation status. - Brill Academic Publishers, Leiden, 512 pp. https://doi.org/10.1163/9789004211810

Felix, J., Nathorst, A. G. (1893): Versteinerungen aus dem mexikanischen Staat Oaxaca. - In: Felix, J., Leuk, H. (eds), Beiträge zur Geologie und Paläontologie der Republik Mexico, Teil 2. A. Felix, Leipzig, pp. 39-54.

Fontaine, W. M. (1889): The Potomac or younger Mesozoic flora. - United States Geological Survey Monographs, 15: 1-377.

Friis, E. M., Crane, P. R., Pedersen, K. R. (1988): Reproductive structure of Cretaceous Platanaceae. - Biologiske Skrifter, Det Kongelige Danske Videnskabernes Selskab, 31: 1-55.

Friis, E. M., Crane, P. R., Pedersen, K. R. (2011): Early flowers and angiosperm evolution. - Cambridge University Press, Cambridge, New York, Melbourne, Madrid, 
Cape Town, Singapore, São Paulo, Delhi, Tokyo, Mexico City, 596 pp.

https://doi.org/10.1017/CBO9780511980206

Friis, E. M., Crane, P. R., Pedersen, K. R., Stampanoni, M., Marone, F. (2015a): Exceptional preservation of tiny embryos documents seed dormancy in early angiosperms. - Nature, 528: 551-554.

https://doi.org/10.1038/nature16441

Friis, E. M., Grimm, G. W., Mendes, M. M., Pedersen, K. R. (2015b): Canrightiopsis, a new Early Cretaceous fossil with Clavatipollenites-type pollen bridge the gap between extinct Canrightia and extant Chloranthaceae. - Grana, 54: 184-212. https://doi.org/10.1080/00173134.2015.1060750

Friis, E. M., Mendes, M. M., Pedersen, K. R. (2018): Paisia, an Early Cretaceous eudicot angiosperm flower with pantoporate pollen from Portugal. - Grana, 57: 1-15. https://doi.org/10.1080/00173134.2017.1310292

Friis E. M., Pedersen, K. R., Crane, P. R. (2013): New diversity among chlamydospermous seeds from the Early Cretaceous of Portugal and North America. - International Journal of Plant Sciences, 174: 530-558. https://doi.org/10.1086/668250

Friis E. M., Pedersen, K. R., Crane P. R. (1994): Angiosperm floral structures from the Early Cretaceous of Portugal. Plant Systematics and Evolution [Supplement], 8: 31-49. https://doi.org/10.1007/978-3-7091-6910-0_3

Friis, E. M., Pedersen, K. R., Crane, P. R. (1999): Early angiosperm diversification: The diversity of pollen associated with angiosperm reproductive structures in Early Cretaceous floras from Portugal. - Annals of the Missouri Botanical Garden, 86: 259-296. https://doi.org/10.2307/2666179

Friis, E. M., Pedersen, K. R., Crane, P. R. (2009): Early Cretaceous mesofossils from Portugal and eastern North America related to the Bennettitales-Erdtmanithecales-Gnetales group. - American Journal of Botany, 96: 252-283. https://doi.org/10.3732/ajb.0800113

Friis, E. M., Pedersen, K. R., Crane, P. R. (2010): Cretaceous diversification of angiosperms in the western part of the Iberian Peninsula. - Review of Palaeobotany and Palynology, 162: 341-361.

https://doi.org/10.1016/j.revpalbo.2009.11.009

Friis, E. M., Pedersen, K. R, Crane, P. R. (2014): Welwitschioid diversity in the Early Cretaceous: Evidence from fossil seeds with pollen from Portugal and eastern North America. - Grana, 53: 175-196. https://doi.org/10.1080/00173134.2014.915980

Gomez, B., Coiffard, C., Dépré, E., Daviero-Gomez, V., Néraudeau, D. (2008): Diversity and histology of a plant litter bed from the Cenomanian of Archingeay - Les Nouillers (southwestern France). - Comptes Rendus Palevol, 7: 135-144.

https://doi.org/10.1016/j.crpv.2007.12.006

Gomez, B., Martin-Closas, C., Barale, G., Solé de Porta, N., Thévenard, F., Guignard, G. (2002): Frenelopsis (Coniferales: Cheirolepidiaceae) and related male organ genera from the Lower Cretaceous of Spain. - Palaeontology, 45: 997-1036.

https://doi.org/10.1111/1475-4983.00273
Harris, T. M. (1969): Naming of fossil conifer. - In: Santarau, H., Ghosh, A. K., Roy, S. K., Chanda, S., Chaudhuri, S. K. (eds), J. Sen Memorial Volume. Botanical Society of Bengal, Calcutta, pp. 243-252.

Heer, O. (1881): Contributions à la flore fossile du Portugal. - Comissão dos Trabalhos Geológicos de Portugal, Lisboa, $51 \mathrm{pp}$.

Heimhofer, U., Hochuli, P. A., Burla, S., Oberli, F., Adatte, T., Dinis, J. L., Weissert, H. (2012): Climate and vegetation history of western Portugal inferred from Albian near-shore deposits (Galé Formation, Lusitanian Basin). - Geological Magazine, 149: 1046-1064. https://doi.org/10.1017/S0016756812000118

Hernandez-Castillo, G. R., Rothwell, G. W., Mapes, G. (2001): Thucydiaceae fam. nov., with a review and reevaluation of Paleozoic walchian conifers. - International Journal of Plant Sciences, 162: 1155-1185. https://doi.org/10.1086/321920

Hill, C. R., Yang, X. J., Zhou, Z., Doyle, J. C. (2012): Exceptionally preserved conifer twigs of Pseudofrenelopsis from the marine Lower Cretaceous of Yorkshire, England. - Acta Paleontologica Sinica, 51: 395-410.

Hluštík, A. (1988): Pseudofrenelopsis parceramosa (Fontaine) Watson from the Lower Cretaceous of Moravia, Czechoslovakia. - Palaeontographica, Abt. B, 210: 1-8.

Kim, J. H., Seo, J. H., Nam, G. S. (2012): Pseudofrenelopsis cf. parceramosa and its reproductive organs from the Lower Cretaceous Youngdong Group of Korea. Geosciences Journal, 16: 399-407. https://doi.org/10.1007/s12303-012-0034-3

Kvaček, J. (1999): Two conifers (Taxodiaceae) of the Bohemian Cenomanian (Czech Republic, Central Europe). - Acta Palaeobotanica, Supplement 2: 129-151.

Kvaček, J. (2000): Frenelopsis alata and its microsporangiate and ovuliferous reproductive structures from the Cenomanian of Bohemia (Czech Republic, Central Europe). - Review of Palaeobotany and Palynology, 112: 51-78. https://doi.org/10.1016/S0034-6667(00)00035-X

Makaske, B., Nap, R. L. (1995): A transition from a braided to a meandering channel facies, showing inclined heterolithic stratification (Late Weichselian, central Netherlands). - Geologie en Mijnbouw, 74: 13-20.

Mendes, M. M., Barrón, E., Batten, D. J., Pais, J. (2017): A new species of the spore genus Costatoperforosporites from Early Cretaceous deposits in Portugal and its taxonomic and palaeoenvironmental significance. - Grana, 56: 401-409. https://doi.org/10.1080/00173134.2016.1269189

Mendes, M. M., Dinis, J. L., Gomez, B., Pais, J. (2010): Reassessment of the cheirolepidiaceous conifer Frenelopsis teixeirae Alvin et Pais from the Early Cretaceous (Hauterivian) of Portugal and palaeoenvironmental considerations. - Review of Palaeobotany and Palynology, 161: 30-42.

https://doi.org/10.1016/j.revpalbo.2010.03.002

Mendes, M. M., Dinis, J., Pais, J., Friis, E. M. (2011): Early Cretaceous flora from Vale Painho (Lusitanian Basin, western Portugal): an integrated palynological and mesofossil study. - Review of Palaeobotany and Palynology, 166: 152-162. https://doi.org/10.1016/j.revpalbo.2011.04.003 
Mendes, M. M., Dinis, J., Pais, J., Friis, E. M. (2014): Vegetational composition of the Early Cretaceous Chicalhão flora (Lusitanian Basin, western Portugal) based on palynological and mesofossil assemblages. - Review of Palaeobotany and Palynology, 200: 65-81. https://doi.org/10.1016/j.revpalbo.2013.08.003

Miall, A. D. (1996): The Geology of Fluvial Deposits. Springer-Verlag, Berlin, $582 \mathrm{pp}$.

Moreno Sánchez, M., Gómez Cruz, A. de J., Castillo González, H. (2007): Frenelopsis y Pseudofrenelopsis (Coniferales: Cheirolepidiacea) en el Cretácico temprano de Colombia [Frenelopsis and Pseudofrenelopsis (Coniferales: Cheirolepidiacea) from Early Cretaceous of Columbia]. - Boletín de Geología, 29: 13-19. (in Spanish)

Nathorst, A. G. (1893): Pflanzenreste aus dem Neokom von Tlaxiaco. - In: Felix, J., Lenk, H. (eds), Beiträge zur Geologie und Paläontologie der Republik Mexico. Teil 2. A. Felix, Leipzig, pp. 51-54.

Néraudeau, D., Allain, R., Ballèvre, M., Batten, D. J., Buffetaut, E., Colin, J. P., Dabard, M. P., Daviero-Gomez, V., El Albani, A., Gomez, B., Grosheny, D., Le Lœuff, J., Leprince, A., Martín-Closas, C., Masure, E., Mazin, J.-M., Philippe, M., Pouech, J., Tong, H., Tournepiche, J.-F., Vullo, R. (2012). The Hauterivian - Barremian lignitic bone bed of Angeac (Charente, south-west France): stratigraphical, palaeobiological and palaeogeographical implications. - Cretaceous Research, 37: 1-14. https://doi.org/10.1016/j.cretres.2012.01.006

Peixoto Batista, M. E., da Costa Silva, D., Sales, M. A. F., Sá, A. A., Saraiva, A. A. F., Bezerra Loiola, M. I. (2017): New data on the stem and leaf anatomy of two conifers from the Lower Cretaceous of the Araripe Basin, northeastern Brazil, and their taxonomic and paleoecological implications. - PLoS ONE 12(3): e0173090 (18 pp.). https://doi.org/10.1371/journal.pone.0173090

Plotnick, R. E., Kenig, F., Scott, A. C., Glasspool, I. J., Eble, C. F., Lang, W. J. (2009): Pennsylvanian paleokarst and cave fills from northern Illinois, USA: A window into late Carboniferous environments and landscapes. - Palaios, 24: 627-637.

https://doi.org/10.2110/palo.2009.p09-012r

Rey, J. (1993): Les unités lithostratigraphiques du Groupe de Torres Vedras (Estremadura, Portugal). - Comunicações do Instituto Geológico e Mineiro, 79: 75-85.

Rey, J. (2006): Stratigraphie séquentielle et séquences de dépôt dans le Crétacé inférieur du Bassin Lusitanien. Ciências da Terra, volume especial 6: 1-120.

Reymanówna, M., Watson, J. (1976): The genus Frenelopsis Schenk and the type species Frenelopsis hoheneggeri (Ettingshausen) Schenk. - Acta Palaeobotanica, 17: 17-26.

Saporta, G. de (1873): Notice sur les plantes fossils du niveau des lits a poissons de Cerin. - In: Thiollière, F. V. (ed.), Description des poissons fossiles provenant des gisements coralliens du Jura dans le Bugey (Seconde livraison). H. Georg, Lyon, F. Savy, Paris, pp. $27-41$.

Saiki, K. (1999): A new cheirolepidiaceous conifer from the Lower Cretaceous (Albian) of Hokkaido, Japan. - Paleontological Research, 3: 29-35.

Schenk, A. (1869): Beiträge zur Flora der Vorwelt (III. Die fossilen Pflanzen der Wernsdorfer Schichten in den Nordkarpathen). - Palaeontographica, 19(1): 1-34.
Seward, A. C. (1895): Catalogue of Mesozoic Plants in the Department of Geology, British Museum (Natural History). The Wealden flora. Part II. - Gymnospermae. - Printed by order of the Trustees, London, $543 \mathrm{pp}$.

Srinivasan, V. (1995): Conifers from the Puddledock locality (Potomac Group, Early Cretaceous) in eastern North America. - Review of Palaeobotany and Palynology 89: 257-286. https://doi.org/10.1016/0034-6667(95)00010-8

Sucerquia, P. A., Bernardes-de-Oliveira, M. E. C., Mohr, B. A. (2015): Phytogeographic, stratigraphic, and paleoclimatic significance of Pseudofrenelopsis capillata sp. nov. from the Lower Cretaceous Crato Formation, Brazil. - Review of Palaeobotany and Palynology, 222: 116-128. https://doi.org/10.1016/j.revpalbo.2015.07.012

Sun, B., Dai, J., Wang, Y., Jia, H., Yan, D., Jiang, Z. (2011): Pseudofrenelopsis fossils from Cretaceous gypsum beds in Guixi, Jiangxi Province, China and their geological significance. - Island Arc, 20: 43-56. https://doi.org/10.1111/j.1440-1738.2010.00719.x

Takhtajan, A. L., Vakhrameev, V. A., Radchenko, G. P. (eds) (1963): Osnovy paleontologii, 15: Golosemennye i pokrytosemennye [Fundamentals of paleontology, vol. 15: Gymnosperms and angiosperms]. - Gosudarstvennoe nauchno-tekhnicheskoe izdatel'stvo literatury po geologii i okhrane nedr, Moskva, 743 pp. (in Russian)

Tanrikulu, S., Doyle, J. A., Delusina, I. (2018): Early Cretaceous (Albian) spores and pollen from the Glen Rose Formation of Texas and their significance for correlation of the Potomac Group. - Palynology, 42: 438-456. https://doi.org/10.1080/01916122.2017.1374309

Villanueva-Amadoz, U., Sender, L. M., Royo-Torres, R., Verdú, F. J., Pons, D., Alcalá, L., Diez, J. B. (2014): Palaeobotanical remains associated with dinosaur fossils from the Camarillas Formation (Barremian) of Galve (Teruel, Spain). - Historical Biology, 27: 374-388. https://doi.org/10.1080/08912963.2014.931385

Watson, J. (1977): Some Lower Cretaceous conifers of the Cheirolepidiaceae from the USA and England. - Palaeontology, 20: 715-749.

Watson, J. (1983): A new species of the conifer Frenelopsis from the Cretaceous of Sudan. - Botanical Journal of Linnean Society, 86: 161-167. https://doi.org/10.1111/j.1095-8339.1983.tb00723.x

Watson, J. (1988): The Cheirolepidiaceae - In: Beck, C. B. (ed.), Origin and evolution of gymnosperms. Columbia University Press, New York, pp. 382-447.

Watson, J., Alvin, K. L. (1976). Silicone rubber casts of silicified plants from the Cretaceous of Sudan. - Palaeontology, 19: 641-650.

Watson, J., Alvin, K. L. (1996): An English Wealden floral list, with comments on possible environmental indicators. - Cretaceous Research, 17: 5-26. https://doi.org/10.1006/cres.1996.0002

Watson, J., Alvin, K. L. (1999): The cheirolepidiaceous conifers Frenelopsis occidentalis Heer and Watsoniocladus valdensis (Seward) in the Wealden of Germany. - Cretaceous Research, 20: 315-326. https://doi.org/10.1006/cres.1999.0152

Yang, X.-J., Deng, S. (2007): Discovery of Pseudofrenelopsis gansuensis from the Lower Cretaceous of Wangqing, 
Jilin Province, and its significance in correlation of Cretaceous red beds in China. - Acta Geologica Sinica, 81: 905-910.

https://doi.org/10.1111/j.1755-6724.2007.tb01012.x

Zbyszewski, G., Assunção, C. T. (1965): Carta Geológica de Portugal na escala 1: 50 000. Notícia explicativa da folha 30-D (Alenquer) [Geological map of Portu- gal at 1: 50000 scale. Explanatory note of sheet 30-D (Alenquer)]. - Serviços Geológicos de Portugal, Lisboa, 104 pp. (in Portuguese)

Zhou, Z. (1983): A heterophyllous cheirolepidiaceous conifer from the Cretaceous of East China. - Palaeontology, 26: 789-811. 